In the brief twenty-one years he was in aviation Mr. Mitchell became recognised as one of the leading designers of the world, and had he lived there is little doubt he would have continued to stand out head and shoulders among most of his contemporaries. He was a nember of Council and was elected to the Society in 1918 , and awarded its Silver Medal in 1927.

The following is an appreciation of Mr. Mitchell by one who worked in close association with him :-

" I feel impelled as one who has worked for R.J. to express a few words of appreciation. All who have worked for him or under him have had a rare opportunity to see how careful consideration and genius can be perfectly applied. His was a quiet, subtle not obvious genius, and has often been mistaken for luck. 'Lucky Mitchell' he was called sometimes, but there wasn't really much luck. His intuitive capacity for grasping the essentials, getting to the point and staying there, was one of his great characteristics. A corollary to this was his uncanny ability to detect errors in involved estimations or calculations by the application of simple common sense. His mind was difficult to follow when on a problem, partly because he was a man of few words and said nothing unless there was something worth saying, but mainly because most people's minds tend to rush on and over obstacles, whereas he would stick at a snag day after day until every aspect of every solution was clear. Then instead of a snap decision he would make a considered compromise.

"He once said in connection with aeroplane design: 'Don't do to-day what you can put off until to-morrow, for premature decisions are often what have killed promising designs. R.J. mistrusted complex theory and involved calculations because in spite of their impressiveness they so easily lead one up the garden. He would say that unless an estimation can be done in a few minutes, it is not worth doing, or that practically any result can be obtained with sufficient accuracy by an approximation. R.J. brought a completely open mind to bear on each new design. He didn't hamper himself by former ideas and decisions. on new work. Every possible scheme would be investigated. In his opinion experience was more important than theory, and he would ask the advice and study the experience of many people, and not only of those in closest touch with him. Suggestions from any member of his staff were always welcomed, and he never turned down a suggestion because he had turned it down once before. Even proposals to which he reacted unfavourably would not be dismissed without thorough investigation. After gathering so many and varied opinions, his genius. asserted itself by his ability to digest them and grasp the essential truth. His designs were thus brilliant compromises, showing little of the development of a single idea such as may be seen in other cases. This freedom from set ideas enabled him to produce outstanding designs of widely varying type, such as Southampton II, the Schneider Trophy seaplanes and the Spitfire, which in their times were or are the best of their kind in the world."

\title{
Brigadier-General Sir CAPEL HoLden, Fellow, 1856-1937.
}

Brigadier Sir Capel Holden died on March 3oth, 1937. The eldest son of the Rev. Dr. H. A. Holden, he joined the R.A. in 1875 . He was a brilliant engineer and the inventor of many instruments and apparatus for artillery and electrical science. He was elected a Fellow of the Royal Society in I895, became Vice-Chairman of the Royal Aero Club, Vice-President of the Institution of Electrical Engineers and of the Royal Society of Arts. He was Chairman of theRoyal Automobile Club in 1905, served on the board of the National Physical Laboratory from 1907 to I9I I, read the James Forrest lecture before the Institution of Civil Engineers in 1908 and was President of the Radio Society of Great: Britain in 1927 .

Sir Capel Holden was elected to the Society in 1913. 